\title{
Characterization of Phosphorus in Fresh and Composted Manures of Different Livestock
}

\author{
Faridullah Faridullah ${ }^{1 *}$, Sahira Hafeez ${ }^{1}$, Toqeer Ahmed ${ }^{2 * *}$, Sadia Alam ${ }^{3}$, \\ Alia Naz ${ }^{4}$, Wisal Shah ${ }^{4}$, Salma Khalid ${ }^{5}$ \\ ${ }^{1}$ Department of Environmental Sciences, COMSATS Institute of Information Technology, \\ Abbottabad-campus, Abbottabad-22060, Pakistan) \\ ${ }^{2}$ Centre for Climate Research and Development, COMSATS Institute of Information Technology, \\ Park Road, Chak Shahzad, Islamabad-45550, Pakistan \\ ${ }^{3}$ Department of Microbiology, University of Haripur, Haripur- 22120, KP, Pakistan \\ ${ }^{4}$ Department of Environmental Sciences, University of Haripur, Haripur- 22120, KP, Pakistan \\ ${ }^{5}$ Environmental Protection and Health Research Unit, Prime Institute of Public Health, \\ Peshawar-25120, Pakistan
}

Received: 29 November 2016

Accepted: 8 Februay 2017

\begin{abstract}
The characterization of phosphorous (P) from animal manure is important for sustainable nutrient management. $\mathrm{P}$ fractions in fresh and composted animal manure was compared for the release of phosphorous fraction to determine heavy metals ( $\mathrm{Fe}, \mathrm{Zn}, \mathrm{Mn}, \mathrm{Ni}$, and $\mathrm{Hg}$ ). Composted and fresh animal manure were collected from four different sources: buffalo (BF), cow (CW), goat (GT), and poultry (PL). The $\mathrm{P}$ fraction was determined by using the Hadley sequential fractionation method. The $\mathrm{P}$ was step-wise fractionated into water-soluble extracted $\mathrm{P}\left(\mathrm{H}_{2} \mathrm{O}-\mathrm{P}\right)$, plant available $\left(\mathrm{NaHCO}_{3}-\mathrm{P}\right), \mathrm{Al}$ associated $(\mathrm{NaOH}-\mathrm{P})$, and $\mathrm{Ca}$ associated (HCl-P). The overall $\mathrm{P}$ fractions extracted by reagents varied in the order $\mathrm{HCl}>\mathrm{NaOH}>$ $\mathrm{NaHCO}_{3}>\mathrm{H}_{2} \mathrm{O}$. The metal concentration varied as follows: $\mathrm{Fe}>\mathrm{Hg}>\mathrm{Mn}>\mathrm{Zn}>\mathrm{Ni}$. The highest $\mathrm{P}$ content was found in composted PL manure whereas the minimum was observed in fresh PL. Consequently, the composed animal manure could be an economical P source to be used as fertilizer.
\end{abstract}

Keywords: composting, fractionations, livestock, manure, $\mathrm{P}$

\section{Introduction}

Phosphorus $(\mathrm{P})$ is considered one of the most important nutrients for plant growth. It is used as a fertilizer either commercially available or in the form of manure, and also plays a key role in the growth of livestock. Animal manure of one of the sources of $\mathrm{P}$. The concentration of $\mathrm{P}$

*e-mail: faridullah@ciit.net.pk

**e-mail: toqeer.ahmed@comsats.edu.pk varies with the age of livestock, diet, and bedding type. It also depends on the livestock species. P found in animal manure exists in organic and inorganic form. In general, $45-90 \%$ of manure $\mathrm{P}$ is inorganic in nature and the other is supposed to be organic $\mathrm{P}$ [1]. Composted manure is richer in organic nutrients than fresh manure [2]. However, fresh, non-composted manure has higher nitrogen $(\mathrm{N})$ content than the composted manure. Fresh manure may contain high amounts of viable weed seeds. In addition, various pathogens may be present in fresh manure, which can 
cause illness unless proper precautions are taken. On the other hand, the residual effects of the manure and compost are important. Continuous use of manure or compost can lead to high levels of residual $\mathrm{P}$ and other nutrients, which can potentially be transported to lakes and streams as a runoff or leach to pollute the groundwater. Besides, the presence of heavy metals in composts raises serious concern about the adverse environmental impact. High and excessive accumulation of heavy metals in soil and other media contaminate both human and animal food chains [3-4]. Overuse of synthetic fertilizers has resulted in serious environmental concerns in many industrial countries, while in developing countries they are neither available nor affordable. Economic and environmental issues associated with intensive use of chemical fertilizers have thus generated an interest in alternative management systems. The application of PL waste to agricultural lands has resulted in excessive soil $\mathrm{P}$ in many locations. If over applied, poultry manure can be a source of $\mathrm{P}$ enrichment of watersheds [5]. Excess soluble P could endanger surface water quality through eutrophication [6]. To address these concerns, many countries in the world have established specific guidelines and standards for the application of composts in agricultural lands.

Because of environmental concerns, future applications of organic amendments should be based on $P$ content. Animal manure and bedding materials contain $\mathrm{P}$ in organic forms. After microbial mineralization from the organic forms, the $\mathrm{P}$ applied to soils is subject to the same fates as inorganic fertilizer P. The application of animal wastes should be based on soil tests, nutrient content of the material, and crop needs. The phosphate in fertilizers and manure is soluble. Manure contains soluble phosphate, organic phosphate, and inorganic phosphate compounds. Agronomic practices are aimed at reducing the dependence on inorganic fertilizers for sustainable agriculture. One of the measures being adopted for relieving environmental problems arising from agricultural production is to recycle animal manure and other organic products as fertilizers [7-9]. Detailed

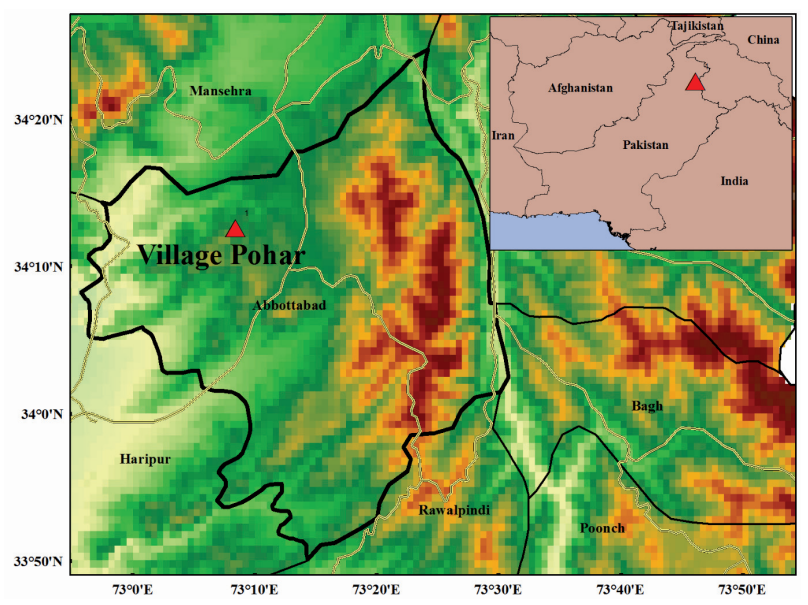

Fig. 1. Study area of Pohar village in Abbottabad District (source: Google Maps). information about the chemical composition of soil $\mathrm{P}$ is necessary to understand the plant nutrient and soil biogeochemical cycles as the soil $\mathrm{P}$ forms vary widely in bioavailability [10]. Sequential extraction procedures are used to fractionate soil inorganic and organic $\mathrm{P}$ according to its chemical stability [11]. Characterization of $\mathrm{P}$ in the animal waste may help to ascertain the behavior of $\mathrm{P}$ and identify sustainable field management practices to reduce possible $\mathrm{P}$ losses. The objectives of the present study were to compare different types of fresh and composted animal manure for the release of $\mathrm{P}$ fraction and to determine heavy metals (Fe, $\mathrm{Zn}, \mathrm{Mn}, \mathrm{Ni}$, and $\mathrm{Hg}$ ) in composted and fresh manure.

\section{Experimental}

\section{Study area}

The present study was conducted in the village of Pohar in the Abbottabad District located in Hazara division of Khyber Pakhtunkhwa Province of Pakistan (Fig. 1). Total area of the district is $1,969 \mathrm{~km}^{2}$ along with Abbottabad city, which is its major urban area. Approximate population of the district is 1.182 million.

\section{Sampling and Analysis}

Animal compost and fresh manure samples of cow, buffalo, poultry, and goat were collected, air dried, crushed, and sieved $(<0.5 \mathrm{~mm}$ pore size). The sieved samples were digested in a mixture of duplicate acids $\left(\mathrm{HNO}_{3}\right.$ and $\left.\mathrm{HClO}_{4}\right)$. Metals $(\mathrm{Ni}, \mathrm{Fe}, \mathrm{Zn}$, and $\mathrm{Hg}$ ) in the extract of digested manure samples, were determined by atomic absorption spectrophotometer [12]. Samples weighing $0.25 \mathrm{~g}$ were digested with $5 \mathrm{~mL}$ concentrated $\mathrm{HClO}_{4}$ by gradual heating. After drying, $20 \% \mathrm{HNO}_{3}$ was added to the sample and it was heated again for $1 \mathrm{~h}$. The solution was diluted to $50 \mathrm{~mL}$ with deionized water and passed through a $0.22 \mu \mathrm{m}$ filter. The $\mathrm{P}$ was determined on a spectrophotometer using the phosphor molybdate blue method [13]. Absorbance was determined at a wavelength of $710 \mathrm{~nm}$. The manure samples were extracted for watersoluble $\mathrm{K}, \mathrm{Ca}, \mathrm{Mg}$, and other metals using de-ionized water. A water extract removes only the easily dissolved form of elements but very little of the adsorbed and mineral forms ( $\mathrm{K}, \mathrm{Ca}, \mathrm{Mg}$, and other metals) were determined on a polarized Zeeman atomic absorption spectrophotometer (Model Z-2300, Hitachi, Japan). Soil pH was measured in soil-water (1:5; w:v) suspensions (Table 1). Treatments were replicated thrice.

\section{P Fractionation}

Manure samples weighing $0.5 \mathrm{~g}$ were placed in a $100 \mathrm{~mL}$ centrifuge tube. $\mathrm{P}$ fractions were determined by the modified sequential extraction procedure of Hedley et al. [14], as described by Ajiboye et al. [15]. The fresh and composted manure samples weighing $0.5 \mathrm{~g}$ were 
Table 1. Physico-chemical properties of manure.

\begin{tabular}{|c|c|c|c|c|c|c|c|c|}
\hline \multirow{3}{*}{ Manure type } & \multirow{2}{*}{ Livestock Sources } & \multicolumn{3}{|c|}{ Water Soluble } & \multicolumn{4}{|c|}{$\mathrm{H}_{2} \mathrm{SO}_{4}+\mathrm{HNO}_{3}$} \\
\cline { 3 - 10 } & & $\mathrm{K}$ & $\mathrm{Ca}$ & $\mathrm{Mg}$ & $\mathrm{K}$ & $\mathrm{Ca}$ & $\mathrm{Mg}$ & $\mathrm{pH}$ \\
\hline \multirow{3}{*}{ Fresh } & $\mathrm{GT}$ & 239 & 174.6 & 419.5 & 438.0 & 395.7 & 879.7 & 7.7 \\
\cline { 2 - 11 } & $\mathrm{BF}$ & 163.8 & 217.2 & 447.8 & 333.4 & 414.6 & 860.6 & 7.6 \\
\cline { 2 - 10 } & $\mathrm{CW}$ & 81.6 & 263.2 & 708.3 & 139.4 & 322.3 & 875.5 & 7.5 \\
\cline { 2 - 10 } & $\mathrm{PL}$ & 119.9 & 153.3 & 618.4 & 190.7 & 243.7 & 900.5 & 7.6 \\
\hline \multirow{3}{*}{ Compost } & $\mathrm{GT}$ & 77.5 & 194.8 & 586.4 & 294.1 & 302.8 & 836.7 & 7.3 \\
\cline { 2 - 10 } & $\mathrm{BF}$ & 114.4 & 333.3 & 717.6 & 249.3 & 423.2 & 857.3 & 7.4 \\
\cline { 2 - 10 } & $\mathrm{CW}$ & 80.3 & 224.0 & 630.8 & 164.3 & 409.2 & 860.0 & 7.6 \\
\hline
\end{tabular}

Source: Faridullah et al. [60]

Note: for subsequent figures $\mathrm{BF}=$ buffalo (fresh and compost); $\mathrm{CW}=\mathrm{cow}$ (fresh and compost), GT= goat (fresh and compost); $\mathrm{PL}=$ poultry (fresh and compost); and $\mathrm{P}, \mathrm{K}, \mathrm{Ca}$, and $\mathrm{Mg}$ = water-soluble phosphorus, potassium, calcium, and magnesium; and $\mathrm{H}_{2} \mathrm{SO}_{4}+\mathrm{HNO}_{3}=$ (double acid digestion total elements)

placed in a $50 \mathrm{~mL}$ centrifuge tube and were fractionated into readily plant-available $\mathrm{P}$, labile inorganic $\mathrm{P}$ (another plant-available fraction), Al-associated inorganic $\mathrm{P}$, and Ca-associated $\mathrm{P}$ by sequential extraction with $30 \mathrm{~mL}$ of de-ionized water, $0.5 M \mathrm{NaHCO}_{3}(\mathrm{pH} 8.5), 0.1 M \mathrm{NaOH}$, and $1 \mathrm{MHCl}$, respectively. For each extraction, the material was shaken for $16 \mathrm{~h}$ at room temperature. After each end-to-end shaking the tubes were centrifuged at $10,000 \mathrm{rpm}$ for $10 \mathrm{~min}$., and the supernatants were filtered by a $0.2 \mu \mathrm{m}$ filter. The shaking/filtering cycle was repeated for all the extracts. Total metals in the samples were determined with a mixture of $\mathrm{HClO}_{4}$ $\mathrm{HNO}_{3}$ [12]. Samples weighing $0.25 \mathrm{~g}$ were digested with $5 \mathrm{~mL}$ concentrated $\mathrm{HClO}_{4}$ by gradually heating it over a hot water bath for $1 \mathrm{~h}$. After drying, $20 \% \mathrm{HNO}_{3}$ was added to the sample and it was heated again for $1 \mathrm{~h}$. The solution was diluted to $50 \mathrm{~mL}$ with deionized water and passed through a $0.22 \mu \mathrm{m}$ filter. P was determined on a spectrophotometer using the phosphomolybdate blue method [13]. Absorbance was determined at a wavelength of $710 \mathrm{~nm}$. Samples were replicated three times. Data were analyzed using Stat view (SAS, 1999) software [16]. Means were compared for P fractions by LSD-test at 0.05 level of significance.

\section{Results and Discussion}

$\mathrm{P}$ fractionation of composted and fresh manure showed that the $\mathrm{P}$ forms changed significantly during fractionation. The overall sequential extraction for reagents considerably varied for $\mathrm{P}$ in the order $\mathrm{HCl}>$ $\mathrm{NaOH}>\mathrm{NaHCO}_{3}>\mathrm{H}_{2} \mathrm{O}$. The mean levels for the release of $\mathrm{P}$ obtained in water were higher in fresh and varied in the order of $(\mathrm{PL})>(\mathrm{CW})>(\mathrm{GT})>(\mathrm{BF})$, whereas $\mathrm{P}$ levels in the compost were $\mathrm{PL}>\mathrm{CW}>\mathrm{GT}>\mathrm{BF}$. Water- soluble extracted $\mathrm{P}$ increased to the maximum in fresh PL $\left(154.0 \mathrm{mgkg}^{-1}\right)$ and the lowest was noted in BF compost $\left(89 \mathrm{mgkg}^{-1}\right)$ as shown in Fig. 2. Sharpley and Moyer [6] reported a reduction in water-soluble $\mathrm{P}$ following the composting of poultry manure, apparently due to the diluting effect of the added $\mathrm{C}$ sources, whereas Sikora and Enkiri [17] found no significant effect of composting on water-soluble P. The mean levels for the release of $\mathrm{P}$ obtained in $\mathrm{NaHCO}_{3}$ was the maximum in composted manure and varied as $\mathrm{PL}>\mathrm{CW}>\mathrm{GT}>\mathrm{BF}$; whereas the concentrations in fresh manure were noted as $\mathrm{PL}>\mathrm{CW}>$ GT $>$ BF (Fig. 2).

Extracted $\mathrm{P}$ increased to the maximum in PL compost $\left(164.5 \mathrm{mgkg}^{-1}\right)$ while the lowest concentration was noted in BF compost ( $\left.99 \mathrm{mgkg}^{-1}\right)$ as shown in Fig. 2. For $\mathrm{NaOH}-$ extracted $\mathrm{P}$, nutrients were greater in composted manures than those observed in the order of $\mathrm{PL}>\mathrm{CW}>\mathrm{BF}>\mathrm{GT}$, where as in fresh it was $\mathrm{PL}>\mathrm{CW}>\mathrm{GT}>\mathrm{BF}$, respectively, maximum concentration was observed in composted PL $\left(99 \mathrm{mgkg}^{-1}\right)$ and the lowest was in fresh BF $\left(86 \mathrm{mgkg}^{-1}\right)$. The low concentration in fresh manure could be due to the use of additives such as ferrous-ferric hydrogen sulfate and alum litter treatments. Moore et al. [18] applied alumtreated poultry litter to pastures for three years and found that soluble reactive $\mathrm{P}$ concentrations in runoff were $75 \%$ lower than normal litter. Concentrations of bioavailable inorganic $\mathrm{P}\left(\mathrm{NaHCO}_{3}\right.$-IP), readily mineralizable organic $\mathrm{P}\left(\mathrm{NaHCO}_{3}-\mathrm{OP}\right)$, potentially bioavailable inorganic $\mathrm{P}$ $(\mathrm{NaOH}-\mathrm{IP})$, and potentially bioavailable organic $\mathrm{P}(\mathrm{NaOH}-$ OP) were still higher in the media amended with compost because of higher total $\mathrm{P}$ concentration in the compost. $\mathrm{P}$ extracted with $\mathrm{HCl}$ in composted manure were $\mathrm{PL}>\mathrm{CW}$ $>\mathrm{GT}>\mathrm{BF}$, while in fresh they varied in the order of PL $>$ $\mathrm{GT}>\mathrm{CW}>\mathrm{BF}$. A higher concentration was found in PL compost $\left(106 \mathrm{mgkg}^{-1}\right)$, whereas the lowest was observed in fresh BF (70 $\left.\mathrm{mgkg}^{-1}\right)$, respectively (Fig. 2). 


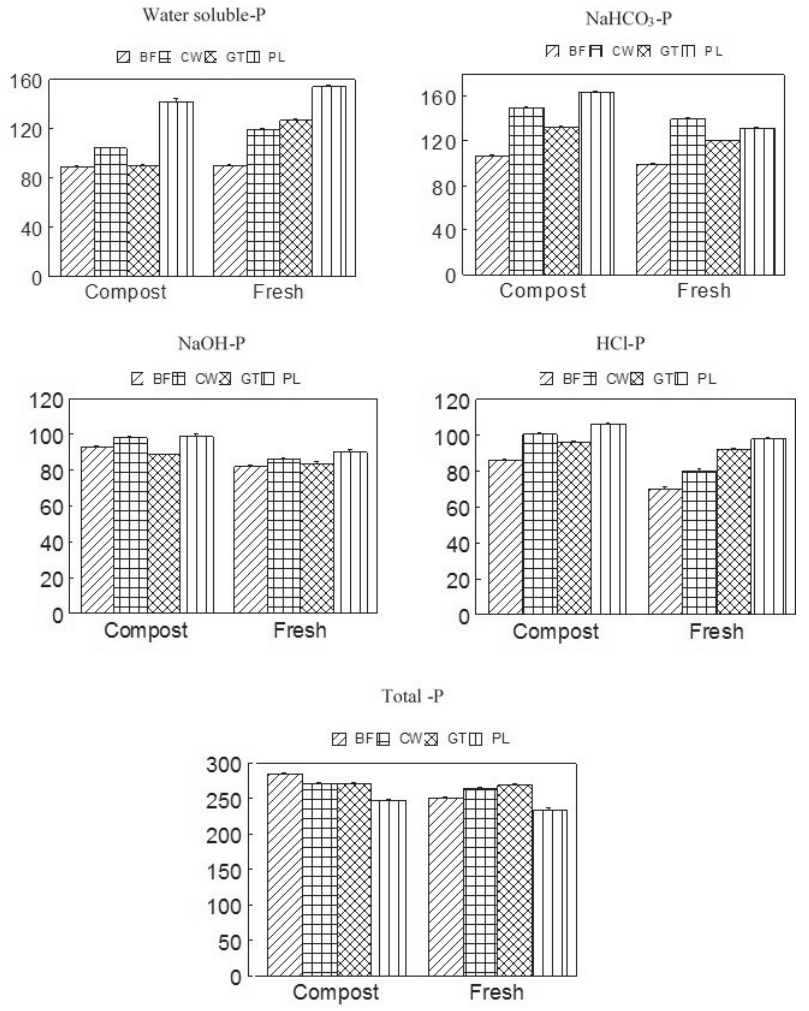

Fig. 2. Phosphorus fractions $\left(\mathrm{mg} \mathrm{kg}^{-1}\right)$ in fresh and composted animal manures.

McDowell and Stewart studied the $\mathrm{P}$ concentration in fresh and dry dung of sheep, cattle, and deer. They found a higher concentration of $\mathrm{P}$ in sheep and reported low bioavailability and decreased $\mathrm{P}$ in dung with drying [19]. Williams et al. [20] found that acid P constitutes stable Ca-bound $\mathrm{P}$ so it would unlikely contribute to the eutrophication of water sources. However, it could be mobilized to labile fraction when the ready $\mathrm{P}$ is depleted. The causes of increased $\mathrm{P}$ availability under reduced conditions have been ascribed to the reductive dissolution of Fe oxides and the liberation of sorbed and occluded P, changes in soil $\mathrm{pH}$ that affect solubility of P-compounds, and the desorption of $\mathrm{P}$ from surfaces [21]. The relative differences observed for the $\mathrm{NaOH}-\mathrm{P}$ fraction across the fertilizer treatments were essentially similar to the HCl-P form. The NaOH-P is a chemisorbed form [20]. It also contains $\mathrm{P}$ associated with humic compounds and $\mathrm{P}$ sorbed to $\mathrm{Fe}$ and $\mathrm{Al}$ oxides. The depletion of water-soluble $\mathrm{P}$ and $\mathrm{NaHCO}_{3} \mathrm{P}$ (the readily available $\mathrm{P}$ ) suggest that these fractions of $\mathrm{P}$ may either be lost through leaching or runoff. The threshold agronomic P level was reported as $20 \mathrm{mg} \mathrm{kg}^{-1}$ soil by [21]. It is also reported that aerobicanaerobic condition changes in $\mathrm{pH}$, and organic matter influence the solubility of $\mathrm{P}$ forms [22]. Cattle fed diets containing the highest concentration of $\mathrm{P}$ also produced manure with the highest concentration of total P [22], but cattle fed on high fat have no impact on manure composition [24].

Eghball and Power [25] suggested that P-based compost or manure application is most effective for corn production and increasing soil phosphorous. Takahashi [26] studies the characterization of the different forms of $\mathrm{P}$ from organic soil amendments by using sequential $\mathrm{P}$ fractionation. He reported that $>60 \%$ of total $\mathrm{P}$ was inorganic, in which major inorganic $\mathrm{P}$ were $\mathrm{NaHCO}_{3}-$ and $\mathrm{HCl}$-extractable $\mathrm{P}$ fractions in the cattle manure composts. Increasing manure concentration resulted in a linear increase in manure water-extractable $\mathrm{P}$ and TP. $\mathrm{P}$ availability from all manure types is high. The $\mathrm{P}$ in manure can be used similarly to $P$ fertilizer. The elevated soil $\mathrm{P}$ on the count of excess manure application is an indicator of its potential transfer from the manure. All the $\mathrm{P}$ forms except water $\mathrm{P}$ were strongly related to total $\mathrm{P}$ in the soil. The concentration of $\mathrm{P}$ extracted by water significantly differed between compost and fresh poultry litter.

The measurement of water-soluble $\mathrm{P}$ in the manure is important because it includes available forms of $\mathrm{P}$ that can immediately be bioavailable and thus have the potential to contribute to environmental contamination. The environmental risk of applying organic amendments depends on their total P content as well as available P [27]. Generally, the $P$ in the compost used in our work is $70 \%$ inorganic, which is readily available for plant absorption, microbial turnover, and soil adsorption. In the last case, when $\mathrm{P}$ sorption capacity reaches saturation, $\mathrm{P}$ can be lost by leaching or surface runoff if the amounts applied exceed crop removal. The biological portion of $\mathrm{P}$ cycle is controlled primarily by bacterial and fungal decomposition, in mobilization, and mineralization. It also varies with plant uptake microbial immobilization and mineralization of $\mathrm{P}$. The amount of fractions was higher in both composted and fresh manure because of the fact that these wastes have been sequentially fractionated in original form and were not applied to the soil.

The $\mathrm{P}$ forms extracted through $\mathrm{NaHCO}_{3}, \mathrm{NaOH}$, and $\mathrm{HCl}$ were found to be higher in composted manure while $\mathrm{H}_{2} \mathrm{O}$-extracted $\mathrm{P}$ was higher in fresh manure. The environmental risks of applying organic amendments depend on their total $\mathrm{P}$ contents as well as forms of $\mathrm{P}$ [27]. Meek et al. (1979) [28] reported an increase in total and available $\mathrm{P}$ due to manure application. Chapuis-Lardy et al. [29] studied the effects of various treatments of cattle slurry manure on water-extractable $\mathrm{P}$. They reported total readily soluble $\mathrm{P}$ content in slurry manures from the nine farms ranging from 1.83 to $4.06 \mathrm{mg} / \mathrm{g}$ of dry matter. A significant percentage of total $\mathrm{P}$ in the slurry manure arose in the water-extractable content, which was $46-71 \%$, and the readily soluble $\mathrm{P}$ fractions was $24-51 \%$. Santillan et al. [30] reported the increase of organic matter after the application of manure and high content of inorganic nitrogen and phosphorous after seven years of manure application. They suggested the monitoring of surface and well-water quality due to leaching and the prevailing application of manure as fertilizers.

Irshad et al. [31] tested the concentrations of plant nutrients like $\mathrm{C}, \mathrm{N}, \mathrm{P}, \mathrm{K}, \mathrm{Na}$, and $\mathrm{B}$ in fresh and composted manures of buffalo, camel, cow, goat, and poultry. They reported increased extractable $\mathrm{P}$ and $\mathrm{B}$ while decreasing 
concentrations of total $\mathrm{N}, \mathrm{C}$, extractable $\mathrm{Na}$, and $\mathrm{K}$ with composting. Similarly, Li et al. [32] conducted a comparative study of characterizing $\mathrm{P}$ in dairy, animal manure, swine, and broilers. They reported that availability, quantity, and $\mathrm{P}$ form varied between different animal manures. Gagnon et al. [33] studies the different forms of $\mathrm{P}$ both in compost and compost-amended soils. They reported that inorganic $\mathrm{P}$ was the most significant form of $\mathrm{P}$ both in the compost and compost-amended soils. Another study reported that $\mathrm{P}$ forms from poultry, cattle, and swine dry manures are bioavailable and in organic in nature and dependent on $\mathrm{Ca}: \mathrm{P}$ ratio in manures [34]. Ajiboye et al. [35] 30 to $40 \%$ of total hog and cattle manure $\mathrm{P}$ and $10 \%$ of total biosolids $\mathrm{P}$ was extracted with water, and 21 to $32 \%$ of total $\mathrm{P}$ in all organic amendments was extracted with $\mathrm{NaHCO}_{3}$ except in dairy cattle manure (45\% of total P).

The manure practices appear to control the chemical forms of heavy metals. The metal contents varied in the order $\mathrm{Fe}>\mathrm{Mn}>\mathrm{Hg}>\mathrm{Ni}>\mathrm{Zn}$ (Fig. 3). The metals in composted manure were observed as $\mathrm{Fe}>\mathrm{Mn}>\mathrm{Hg}>$ $\mathrm{Ni}>\mathrm{Zn}$ and in fresh manure appeared in the order Fe $>\mathrm{Mn}>\mathrm{Ni}>\mathrm{Hg}>\mathrm{Zn}$. A higher concentration of Fe was found in BF compost with (338 $\left.\mathrm{mg} \mathrm{kg}^{-1}\right)$ and the lowest in fresh PL (111 $\left.\mathrm{mg} \mathrm{kg}^{-1}\right)$ as shown Fig. 3. The maximum concentration of $\mathrm{Zn}$ was found in $\mathrm{BF}$ compost (10.35 mg kg-1) and the minimum were in fresh PL (2.3 mg kg-1). A high concentration of $\mathrm{Mn}$ was found in BF compost $\left(71.3 \mathrm{mg} \mathrm{kg}^{-1}\right)$ and low were observed in fresh PL ( $\left.38 \mathrm{mg} \mathrm{kg}^{-1}\right)$ as shown in Fig. 3. The higher concentration of $\mathrm{Ni}$ was observed in $\mathrm{BF}$ compost
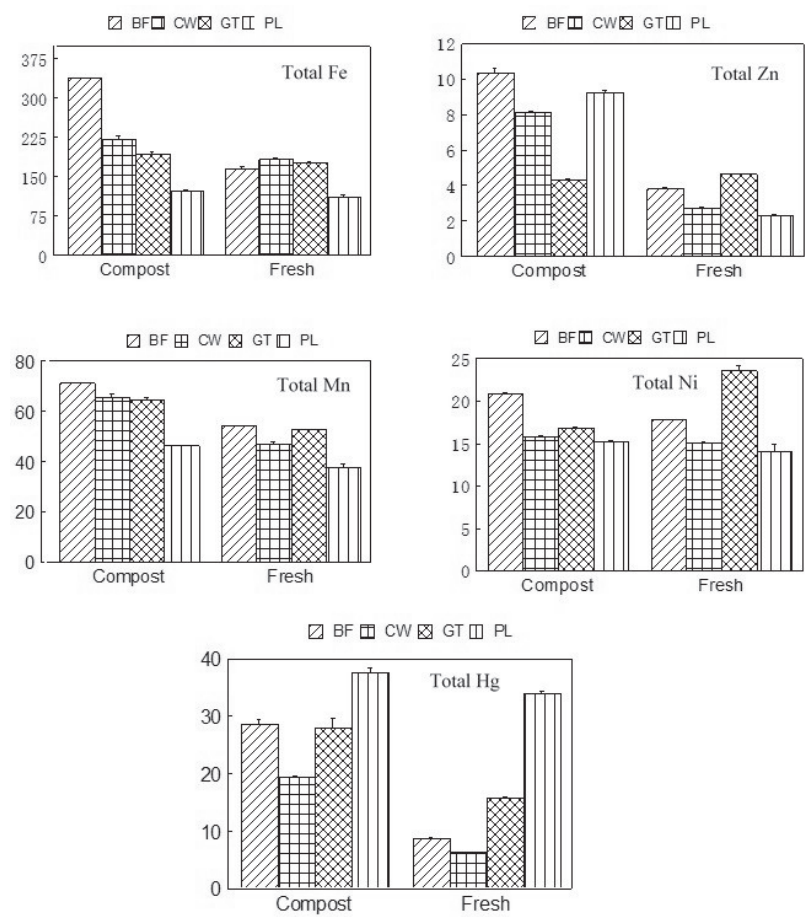

Fig. 3. Total metals $\left(\mathrm{mg} \mathrm{kg}^{-1}\right)$ in fresh and composted animal manures.
(20.8 $\left.\mathrm{mg} \mathrm{kg}^{-1}\right)$ and the lowest in fresh PL $\left(14 \mathrm{mg} \mathrm{kg}^{-1}\right)$ as shown in Fig. 3. The maximum concentration of $\mathrm{Hg}$ was noted in PL compost $\left(37.5 \mathrm{mg} \mathrm{kg}^{-1}\right)$ and minimum in CW fresh $\left(6.2 \mathrm{mg} \mathrm{kg}^{-1}\right)$ as shown in Fig. 3. Faridullah et al. [36] compared the various trace elements in both fresh and composted animal manures by adopting sequential fractionation procedure. They used both fresh and composted manures from four different species of animals like buffalo, cow, goat, and poultry to find fractions of iron, nickel, zinc, mercury, and manganese. They found that $\mathrm{Fe}, \mathrm{Mn}$, and $\mathrm{Hg}$ were in higher concentrations in composted samples, while $\mathrm{Zn}$ and $\mathrm{Ni}$ were meanly higher in fresh manures. Concentrations of heavy metals in plants are affected by sheep manure and inorganic fertilizer, and especially $\mathrm{Pb}, \mathrm{Cd}$, and $\mathrm{Zn}$ concentrations are decreased by the applications of sheep manure in plant tissues [37].

Bolan et al. [9] reported that the concentration of metals in manure can vary considerably depending on the number of factors, including type of livestock (i.e., poultry, swine, or cattle). Within a type, additional variation is associated with the age of the animal, type of ration, housing type, and waste management practice. The metal contents of manure by-product depend primarily on the amount used in the feed and health remedies. Increases in metal concentration in animal feed have often resulted in corresponding increases in their concentrations in the manure by-products [38]. Heavy metals were investigated in 109 samples in Korea and reported that $\mathrm{Zn}$ and $\mathrm{Cu}$ were found at their highest concentrations in compost other than the tested metals [39].

DeLaune and Moore [40] studied the $\mathrm{Cu}$ and $\mathrm{Zn}$ concentrations, which were measured in runoff water collected from plots fertilized with composted and fresh poultry litter and in which were found elevated concentrations of $\mathrm{Cu}$ and $\mathrm{Zn}$ in compost as compared to poultry litter. Another study reported a high concentration of heavy metals in solid municipal waste composting due to uncontrolled leaching, along with runoff and compost, which subsequently degraded water quality and elevated environmental risk [41]. Eneji et al. [6] reported that the major concern of soil pollution with available heavy metals by the use of manures can be minimized through composting under aerobic conditions. The bacterial community plays an important role, especially phosphate-solubilizing bacteria. Wei et al. [42] suggested the combined use of bacteria and biochar as an effective strategy for increasing available $\mathrm{P}$ fraction as both these have important roles in transformation. Vazquez et al. [43] studied the physicochemical quality of compost and reported that compost quality is not affected by moisture (80\%). Pare et al. [44] reported a decrease in the extractability of some heavy metals during composting of biosolids and municipal solid wastes, indicating a reduced risk of their entering the food chain through crops and water. According to Pare et al. [44], proportionally greater increases in humic compounds during composting will cause more heavy metals to interact with sites of greater complexing strengths, where they become less accessible and available to plants and extracting agents. 
According to scientific risk assessment, the presence of cadmium in P-containing fertilizer does not pose any risk to human health [45]. Tian et al. [46] suggested the Caragana microphylla-straw compost as an alternate for excessively fertilized soils, and for reducing environmental risk because excessively fertilized soil releases more nutrients. Phosphorous loss risk coefficient was studied by Robert and reported that soil type, manure type, and their interaction has a significant effect on P loss risk coefficient, which is important for assessing phosphorous and nutrient management in the environment [47]. Some microbes play an important role in increasing soil fertility along with plant growth, but some work in depleting $\mathrm{P}$ and compost clearing [48-49].

Phosphorous absorption by soil is highly important for management practices, depending on different transport factors like soil hydrological conductivity, precipitation, slope, and distance, along with integration, which plays an important role in $\mathrm{P}$ absorption [50]. Leaching of $\mathrm{P}$ and other elements from manure to water sources may affect surface water quality [51-52]. Vermicomposting can play an important role in stabilizing heavy metals in composting animal manures [53]. This can help in achieving finer homogeneity than for a conventional product [54]. Animal manure compost as fertilizer not only is important for crops and plants, but also for cultivating microalgae for the production of different bio-products and waste management, as it is a rich source of nutrients [55]. It is suggested in some studies that metals may be cautiously inspected in both fresh and composted manure before applying it to agriculture [56-57], while in others composting is one of the treatment technologies for solid waste management [58-60].

\section{Conclusions}

The overall sequential extraction for reagents considerably varied for $\mathrm{P}$ in the order of $\mathrm{HCL}>\mathrm{NaOH}$ $>\mathrm{NaHCO}_{3}>\mathrm{H}_{2} 0$. The $\mathrm{P}$ and other nutrients availability increased progressively during composting with the simultaneously decrease in fresh manures. The metals were varied in the order $\mathrm{Fe}>\mathrm{Hg}>\mathrm{Mn}>\mathrm{Zn}>\mathrm{Ni}$ because the type of bedding material in manures may influence its chemical properties. Our results demonstrate that agronomically and environmentally important attributes associated with composted and non-composted manure application can be predicted based on P fractions and an optimization procedure involving regression analysis. Composting animal manures before land application can affect the forms and concentrations of P. The use of composted animal manures as soil amendment could be economically productive and would potentially ameliorate the major concerns associated with animal waste and acid soil management.

\section{Acknowledgements}

The authors gratefully acknowledge the support received from CCRD, CIIT, Islamabad, and CIIT, Abbottabad. This research work received no specific grant from any donor agency in the public, commercial, or not-for-profit sectors, and these organizations have had no involvement in the analysis and interpretation of data, in the writing of the draft, and in the decision to submit the article for publication.

\section{References}

1. BUCKLEY K. AND MAKORTOFF M. P in Livestock Manures. Advanced Silage Corn Management, 2004. http:// www.farmwest.com/node/953 [Last accessed on Nov. 2016].

2. ZUCCONI F., DE BERTOLDI, M. Compost specifications for the production and characterization of compost from municipal solid waste. In: de Bertoldi, M., Ferranti, M.P., L' Hermite, P., Zucconi, F. (Eds.), Compost: Production, Quality and Use. Elsevier, Barking, 30, 1987.

3. HE X.T. LOGAN T.J. TRAINA S.J. Physical and Chemical characteristics of selected US municipal solid waste composts. Journal of Environmental Quality 24, 543, 1995.

4. IWEGBUE C.M.A, NWAJEI G.E., OSAKWE S.A. Recycling waste in agriculture: Efficacy of composting in ameliorating trace metal availability and soil borne pathogens. European J. Sci. Res. 11 (3), 572, 2005.

5. POTE D.H., DANIEL T.C NICHOLS D.J., SHARPLEY A.N., MOORE P.A., MILLER D.M., EDWARDS D.R. Relationship between $\mathrm{P}$ levels in three Ultisols and $\mathrm{P}$ concentrations in runoff. J. Environ. Qual. 28, 170, 1999.

6. SHARPLEY A.N., MOYER B. P forms in manure and compost and their release during simulated rainfall. J. Environ. Qual. 29, 1462, 2000.

7. ENEJI A. E., HONNA T., YAMAMOTO S., IRSHAD M., ENDO T. Changes in humic substances and P fractions during composting. Commun. Soil Sci. Plant Anal. 34, 2303, 2003.

8. ENEJI A.E., YAMAMOTO S., HONNA T. Rice growth and nutrient uptake as affected by livestock manure in four Japanese soils. J. Plant Nutr. 24, 333, 2001.

9. BOLAN N.S., ADRIANO D.C., MAHIMAIRAJA S. Distribution and bioavailability of trace elements in livestock and poultry manure byproducts. Crit Revi. in Env. Sci. and Tech. 34, 291, 2004.

10. GRIFFIN T.S., HONEYCUTT C.W., HE Z. Changes in soil P from manure application. Soil Sci. Soc. Am. J. 67, 645, 2003.

11. POTTER. R.L., JORDAN C.F., GUEDES R.M., LIATMANIAN G.J., HAN X.G. Assessment of a P fractionation method for soils: Problems for further investigation. Agric. Ecosyst. Environ. 34, 453, 1991.

12. IBSRAM. Methodological guidelines for IBSRAM's soil management networks, $2^{\text {nd }}$ ed. International Board for Soil Research and Management, Bangkok, 1994. 
13. MURPHY J., RILEY J.P. A modified single solution method for the determination of $\mathrm{P}$ in natural waters. Anal. Chim. Act. 27, 31, 1962.

14. HEDLEY M.J., STEWART J.W., CHAUHAN B.S. Changes in inorganic and organicsoil $\mathrm{P}$ fractions induced by cultivation practices and by laboratoryincubation. Soil Sci. Soc. Am. J. 46, 970, 1982.

15. AJIBOYE B., AKINRREMI O.O., RACZ G.J. Laboratory characterization of $\mathrm{P}$ in fresh and oven-dried organic amendments. J. Environ. Qual. 33, 1062, 2004.

16. SAS. Stat View reference, third edition, SAS Institute Inc., Cary, NC, USA, 1999.

17. SIKORA L.J., ENKIRI N.K. Comparison of $\mathrm{P}$ uptake from poultry litter compost with triple superphosphate in Codorus soil. Agron. J. 97, 668-, 2005.

18. MOORE P.A., DANIEL T.C., EDWARDS D.K. Reducing $P$ runoff and inhibiting ammonia loss from poultry manure with aluminum sulfate.. JEQ. 29, 37, 2000.

19. MCDOWELL R.W. AND STEWART I. P in Fresh and Dry Dung of Grazing Dairy Cattle, Deer, and Sheep. JEQ. 34 (2), 598, 2004.

20. WILLIAMS J.D., SHEAR H, THOMAS R.L. Availabilty to Scendesmus gradncauda of different forms of $\mathrm{P}$ in sedimentary materials from the Great Lakes. Limnol. Oceanogr. 25, 1, 1980.

21. PONNAMPERUMA F.N. The chemistry of submerged soils. In: (N. C. Brady, (ed)) Advances in agronomy, Vol. 24. Academic, New York. 29, 1972.

22. SHARPLEY A.N. Dependence of runoff P on extractable soil P. J. Environ. Qual. 24, 920, 1995.

23. LEE C. Evaluation of Dairy Manure as Fertilizer: Manure $\mathrm{N}$ and P Supplies for Crop Production. Ohio Agricultural Research and Development Center, The Ohio State University. 2016. http://articles.extension.org/pages/73539/ evaluation-of-dairy-manure-as-fertilizer:-manure-n-and-psupplies-for-crop-production. [last accessed on Nov. 2016].

24. GAUTAM D.P., RAHMAN S., BORHAN M.S., ENGEL C. The effect of feeding high fat diet to beef cattle on manure composition and gaseous emission from a feedlot pen surface. J. Anim. Sci. Technol. 58, 22, 2016.

25. EGHBALL, B., POWER, J.F. P- and Nitrogen-Based Manure and Compost Applications Corn Production and Soil P. Soil Science Society of America Journal. 63 (4), 895.

26. TAKAHASHI S. P characterization of manure composts and combined organic fertilizers by a sequentialfractionation method. J. Plant Nutr. Soil Sci. 176, 494, 2013.

27. SIMS T.J., EDWARDS A.C., SCHOUMANS O.F., SIMARDS R. R. Integrating soil P testing into environmentally based management practices. J. Environ. Qual. 29, 60, 2000.

28. MEEK B.D., GRAHAM L.E., DONOVAN T.J., MAYBERRY K. S. P availability in a calcareous soil after high loading rates of animal manure. Soil Sci. Am. J. 43, 741, 1979.

29. CHAPUIS-LARDY L., TEMMINGHOFF E.J.M., DE GOEDE R.G.M. Effects of different treatments of cattle slurry manure on water-extractable P. NJAS-Wageningen J. Lif. Sci. 51 (1-2), 91, 2003.

30. SANTILLAN Y.M., MORENO F.P., GARCIA F.P., SANDOVAL O.A.A. Effect of the Application of Manure of Cattle on the Properties Chemistry of Soil in Tizayuca, Hidalgo, Mexico. Int. J. Appl. Sci. and Tech. 4 (3), 67, 2014.

31. IRSHAD M., ENEJI A.E., HUSSAIN Z., ASHRAF M. Chemical characterization of fresh and composted livestock manures. J. Soil Sci. and Plant Nutr. 13 (1), 115, 2013.

32. LI G., LI H., LEFFELAAR P.A., SHEN J., ZHANG F. Characterization of $\mathrm{P}$ in Animal Manures Collected from
Three (Dairy, Swine, and Broiler) Farms in China. PLoS ONE 9 (7), 102698, 2014.

33. GAGNON B., DEMERS I., ZIADI N., CHANTIGNY M. H., PARENT L.E., FORGE T.A., LARNEY F.J., BUCKLEY K. E. Forms of $\mathrm{P}$ in composts and in compost-amended soils following incubation. Can. J. Soil Sci. 92, 711, 2012.

34. TIECHER T., ZAFAR M., MALLMANN F.J.K., BORTOLUZZI E.C., BENDER M.A., CIOTTI L.H., DOS SANTOS D.R. Animal manure P characterization by sequential chemical fractionation, release kinetics and ${ }^{31}$ P-NMR analysis. Rev. Bras. Cienc. Solo. 38 (5), 1506, 2014.

35. ELOUEAR, Z., BOUHAMED, F., BOUJELBEN, N., BOUZID J. Application of sheep manure and potassium fertilizer to contaminated soil and its effect on zinc, cadmium and lead accumulation by alfalfa plants. Sustain. Environ. Res., 26, 131, 2016.

36. AJIBOYE B., AKINREMI O.O., RACZ G.J. Laboratory Characterization of $\mathrm{P}$ in Fresh and Oven-Dried Organic Amendments. JEQ. 33 (3), 1062, 2003.

37. FARIDULLAH PERVAIZ A., IRSHAD M., ALAM A., MAHMOOD Q., ASHRAF M. Trace Elements Characterization in Fresh and Composted Livestock Manures. Austin J Hydrol. 1 (2),6, 2014.

38. NAHM, K.H. Efficient feed nutrient utilization to reduce pollutants in poultry and swine manure. Rev. Environ. Sci. Tech. 32, 1, 2002.

39. KO H.J., KIM K.Y. Heavy Metals Contents and Chemical Characteristics in Compost from Animal Manures. J. Kor. Soc. Occup. \& Env. Hyg. 26 (2), 170, 2016.

40. DELAUNE P.B., MOORE P.A. Copper and Zinc Runoff from Land Application of Composted Poultry Litter. 45 (5), 1565, 2016.

41. SHARIFI Z., HOSSAINI S.M.T., RENELLA G. Risk assessment for sediment and stream water polluted by heavy metals released by a municipal solid waste composting plant. J. of Geochem. Explo. 169, 202, 2016.

42. WEI Y., ZHAO Y., WANG H., LU Q.,CAO Z., CUI H., ZHU L., WEI Z. An optimized regulating method for composting $\mathrm{P}$ fractions transformation based on biochar addition and phosphate-solubilizing bacteria inoculation. Bioreso. Tech. 221, 139, 2016.

43. VAZQUEZ, M.A., SEN, R., SOTO, M. Physico-chemical and biological characteristics of compost from decentralized composting programmes. Biores. Tech. 198, 520, 2015.

44. PARE T., DINEL H., SCHNITZER, M. Extractability of trace metals during co-composting of biosolids and municipal solid wastes. Biol. Fertil. Soils, 29, 31, 1999.

45. WANG Y.T., ZHANG T.Q., HU Q.C., TAN C.S. P source coefficient determination for quantifying $\mathrm{P}$ loss risk of various animal manures. Geoderma. 278, 23, 2016.

46. TIAN Y., WANG Q., ZHANG W., GAO L. Reducing environmental risk of excessively fertilized soils and improving cucumber growth by Caragana microphyllastraw compost application in long-term continuous cropping systems. Sci. Tot. Env. 544, 251, 2016.

47. ROBERTS T.L. Cadmium and Phosphorous Fertilizers: Issu. and Sci. Proc. Eng. 83, 52, 2014.

48. HARMAN, G.E. Overview of mechanisms and uses of Trichoderma spp. Phytopathology 96, 190, 2006.

49. CHANDNA P., NAIN L., SINGH S., KUHAD R.C. Assessment of bacterial diversity during composting of agricultural byproducts. BMC Microbiol. 13 (99), 1, 2013.

50. WANG Y.T., O'HALLORAN I.P., ZHANG T.Q., HU Q.C., TAN C.S. P sorption parameters of soils and their 
relationships with soil test P. Soil Sci. Soc. Am. J., 79, 672, 2015.

51. US-EPA. Estimated Animal Agriculture Nitrogen and P from Manure. Department of Agriculture, 2009. https:// www.epa.gov/nutrient-policy-data/estimated-animalagriculture-nitrogen-and-P-manure [accessed on 18 Nov. 2016].

52. HE Z., PAGLIARI P., WALDRIP H. Applied and Environmental Chemistry of Animal Manure: A Review. Pedosphere 26 (6), 779, 2016.

53. LV B., XING, M., YANG, J. Speciation and transformation of heavy metals during vermicomposting of animal manure. Bioreso. Tech. 209, 397, 2016.

54. HANC A., DRESLOVA M. Effect of composting and vermicomposting on properties of particle size Fractions. Bioreso. Tech. 217, 186, 2016.

55. ZHU L.D., HILTUNEN E. Application of livestock waste compost to cultivate microalgae for bio products production: A feasible framework. Renew. and Sust. Energ. Rev. 54, 1285, 2016.
56. IRSHAD M., MALIK A.H., SHAUKAT S., MUSHTAQ S., ASHRAF M. Characterization of Heavy Metals in Livestock Manures. Pol. J. Environ. Stud. 22 (4), 1257, 2013.

57. ADESOYE A.M., ADEKOLA F.A., OLUKOMAIYA K.O., OLUKOMAIYA O.O., IWUCHUKWU P.O. Evaluation of physical properties and heavy metal composition of manure of some domestic animals. Int. J. of Inno. and Sci. Res. 14 (9), 293, 2014.

58. WONG J., SELVAM A., AWASTHI M. Composting for Organic Waste Management. Sust. Sol. Wast. Manag. 233, 2016.

59. KIYASUDEEN S.K., IBRAHIM M.K., QUAIK S., ISMAIL S.A. Composting: A Traditional Practice of Waste Treatment. Pros. Org. Wast. Manag. Sig. Earth. 45, 2015.

60. FARIDULLAH F., PERVAIZ A., HAFEEZ S., ALAM A., SHAH S.H., WASEEM A. Evaluating nutrient elements and heavy metals in fresh and composted manures of different livestock. FEB. 23 (8), 2014. 